\title{
Hubungan Host dan Lingkungan dengan Manifestasi Klinis Hepatitis A
}

\author{
Retno Sunartyasih, Luciana Asih Kartikasari \\ Sekolah Tinggi Ilmu Kesehatan Borromeous \\ E-mail: elizabeth.rini@yahoo.com
}

\begin{abstract}
Abstrak
Hepatitis A adalah infeksi sistemik oleh virus hepatitis A yang menyerang organ hati dan penularannya terjadi secara fekal-oral. Penelitian ini dilatarbelakangi oleh adanya mahasiswa sebuah perguruan tinggi swasta sebanyak 160 orang terkena hepatitis A pada bulan Oktober-November 2011, dan mereka telah menjalani rawat jalan maupun rawat inap. Tujuan penelitian ini adalah untuk mengetahui hubungan antara faktor host dan lingkungan dengan manifestasi klinis penyakit hepatitis A pada mahasiswa Universitas X di Bandung. Penelitian ini dilakukan pada bulan Mei-Juni 2012. Populasi dalam penelitian ini adalah mahasiswa yang terkena penyakit hepatitis A dari bulan Oktober-Desember 2011. Sampel dalam penelitian ini berjumlah 114 mahasiswa. Metode yang digunakan adalah kuantitatif dengan desain penelitian survei analisis cross sectional. Analisis data menggunakan Chi-Square. Dari hasil penelitian didapatkan kesimpulan bahwa faktor host dan lingkungan memiliki hubungan dengan manifestasi klinis penyakit hepatitis A dengan nilai $p<0.05$. Kondisi lingkungan juga perlu diperhatikan agar dapat mencegah terjadinya penyakit terutama hepatitis A.
\end{abstract}

Kata kunci: Faktor host, hepatitis A, manifestasi klinis.

\section{The Relationships between Host and Environtment with Clinical Manifestation of Hepatitis A}

\begin{abstract}
Hepatitis A is a common systemic infection transmitted by fecal-oral. This study conducted based on increased hepatitis A incidence among students in a private university in Bandung (October-November 2011). The aimed of this study was to identified the relationship between host and environtment factor with clinical manifestation of hepatitis A in X University's student in Bandung. This study was conducted in May-June 2011. The population of this study was 114 student who experienced hepatitis. A quantitative survey used as a method in this study. The data was analyzed by non parametric chi-square test. Result of this study showed there was a significant relationship between host and clinical manifestation of hepatitis A $(p<0.05)$. Student should have a high body endurance to enhance immunity particulary in a distress condition and mainten health environment to prevent hepatitis A transmission.
\end{abstract}

Key words: Clinical manifestation, hepatitis A, host factor. 
Retno : Hubungan Host dan Lingkungan dengan Manifestasi Klinis Hepatitis A

\section{Pendahuluan}

Sehat menurut World Health Organization (WHO) adalah suatu keadaan yang sempurna baik secara fisik, mental dan sosial serta tidak hanya bebas dari penyakit atau kelemahan (Perry \& Potter, 2005). Dinamika perilaku hidup sehat di dunia saat ini sangat cepat, sehingga masih banyak hal-hal yang kurang diperhatikan, misalnya kebutuhan fisiologis seperti makan atau minum. Kebanyakan orang lebih rentan mengalami berbagai macam gangguan kesehatan baik yang bersifat akut maupun kronis. Salah satu contoh gangguan atau infeksi yang bersifat akut yaitu hepatitis A. Penyakit hepatitis A disebabkan oleh virus hepatitis A (Najmudin, 2011).

Negara Indonesia termasuk kedalam suatu wilayah endemi hepatitis A. Berdasarkan data yang didapat dari rumah sakit di Indonesia, kasus penyakit hepatitis A merupakan kasus yang terbesar dibandingkan dengan kasus hepatitis Akut lainnya (Cahyono, 2009). Hasil survei epidemiologi di beberapa kota seperti di Jakarta, Bandung, dan Makassar menggunakan pemeriksaan anti-HAV, insiden hepatitis A mencapai lebih dari $90 \%$ pada kelompok usia 30 tahun (Cahyono, 2009).

Studi pendahuluan yang dilakukan di Universitas X di Bandung, telah didapatkan data dari bulan Oktober-November 2011 sebanyak 160 mahasiswa telah terdiagnosis penyakit Hepatitis A. Tujuan penelitian ini adalah mengidentifikasikan hubungan antara host dan lingkungan terhadap manifestasi klinis hepatitis A pada mahasiswa Universitas $\mathrm{X}$ di Bandung.

\section{Metode Penelitian}

Metode penelitian yang digunakan dalam penelitian ini adalah metode kuantitatif, dengan desain survei analitik cross sectional. Survei tidak dilakukan kepada seluruh objek yang diteliti atau populasi, tetapi hanya mengambil sebagian dari populasi tersebut atau sampel (Notoatmodjo, 2010). Survei yang digunakan dalam penelitian ini adalah survei analitik. Survei analitik dilakukan dengan cara menggali fenomena kesehatan dapat terjadi. Kemudian melakukan analisis dinamika korelasi antara fenomena atau antara faktor risiko dengan faktor efek. Survei cross sectional dilakukan dengan melihat korelasi antara faktor-faktor risiko dengan efek. Pendekatan yang digunakan melalui teknik observasi atau pengumpulan data sekaligus pada suatu saat (point time approach). Setiap subjek penelitian dilakukan observasi sekali dan pengukuran dilakukan terhadap status karakter atau variabel subjek pada saat pemeriksaan (Notoatmodjo, 2010).

Variabel yang digunakan pada penelitian ini terdiri dari manifestasi klinis penyakit hepatitis A sebagai variabel dependen dan faktor host dan lingkungan mahasiswa sebagai variabel independen. Faktor host dan faktor lingkungan pada mahasiswa Universitas X diukur dengan cara pengisian kuesioner oleh 114 mahasiswa. Kuesioner yang digunakan oleh peneliti terdapat 20 item pertanyaan yang telah diuji kevaliditasannya.

Analisis yang digunakan dalam penelitian ini adalah analisis univariat yang meliputi variabel manifestasi klinis hepatitis $\mathrm{A}$, faktor

Tabel 1 Jumlah Mahasiswa yang Terkena Hepatitis A berdasarkan Jurusan dan Angkatan pada Kurun Waktu Oktober-November 2011

\begin{tabular}{lccccccc}
\hline \multicolumn{1}{c}{$\begin{array}{c}\text { Jurusan } \\
\text { Angkatan }\end{array}$} & $\mathbf{2 0 1 1}$ & $\mathbf{2 0 1 0}$ & $\mathbf{2 0 0 9}$ & $\mathbf{2 0 0 8}$ & $\mathbf{2 0 0 7}$ & $\mathbf{2 0 0 6}$ & $\begin{array}{c}\text { Total per } \\
\text { jurusan }\end{array}$ \\
\hline Teknik Industri & 25 & 14 & 20 & 6 & 6 & 0 & 71 \\
Teknik Kimia & 14 & 5 & 7 & 3 & 1 & 0 & 30 \\
Studi Pembangunan & 0 & 0 & 0 & 2 & 0 & 1 & 3 \\
Manajemen & 4 & 0 & 7 & 2 & 1 & 1 & 15 \\
Akuntansi & 1 & 4 & 4 & 1 & 1 & 1 & 12 \\
T.Informatika & 1 & 9 & 4 & 4 & 0 & 0 & 18 \\
Matematika & 2 & 0 & 2 & 5 & 0 & 0 & 9 \\
\hline
\end{tabular}

Volume 1 Nomor 2 Agustus 2013 
Retno : Hubungan Host dan Lingkungan dengan Manifestasi Klinis Hepatitis A

manusia dan faktor lingkungan mahasiswa universitas X di Bandung. Analisis terakhir yang digunakan adalah analisis bivariat. Setelah diketahui nilai dari masing-masing variabel dan sub variabel maka tahapan selanjutnya adalah analisis bivariat. Dari hasil uji normalitas, dengan menggunakan Kolmogorov Smirnov didapatkan hasil faktor host dan lingkungan, uji signifikan $=0.000(p$ value $<0.05)$ sehingga distribusi data tidak normal.

Pada pengolahan data untuk analisis bivariat menggunakan uji nonparametrik karena distribusi data tidak normal. Uji nonparametrik yang digunakan adalah uji chi-square karena jenis data penelitian adalah kategorik-kategorik.

Populasi pada penelitian ini adalah mahasiswa yang pernah mengalami hepatitis A di Universitas X di Bandung, dalam waktu dua bulan yang berjumlah 160 orang daribulan Oktober-November 2011. Jumlah sampel yang diambil menggunakan penghitungan rumus Notoatmodjo (2010) yaitu:

$$
n=\frac{N}{N(d 2)+1}
$$

Jadi, sampel dalam penelitian ini adalah 114 orang. Teknik sampling yang digunakan dalam penelitian ini adalah Quota Sample atau Sampel Kuota. Peneliti menghubungi subjek yang memenuhi persyaratan sebagai populasi, subjek yang dihubungi yaitu subjek yang mudah untuk ditemui, sehingga pengumpulan data dilakukan dengan cepat (Riyanto, 2011). Cara yang dilakukan oleh peneliti dalam mendapatkan responden yang telah ditetapkan adalah dengan memasukkan kuesioner kedalam amplop yang sudah disertai dengan nama-nama mahasiswa yang terkena penyakit hepatitis A. Kuesioner lalu disebarkan melalui Majelis Perwakilan Mahasiswa (MPM) Universitas X tersebut dan staf kependidikan. Penyebaran kuesioner dilakukan secara langsung oleh peneliti sendiri.

Tabel 2 Distribusi Frekuensi Responden berdasarkan Jenis Kelamin $(n=114)$

\begin{tabular}{lcc}
\hline \multicolumn{1}{c}{ Variabel } & Frekuensi (orang) & Persentase (\%) \\
\hline Jenis Kelamin & 67 & 58,8 \\
Pria & 47 & 41,2 \\
Wanita & & \\
Status Tinggal & 39 & 34,2 \\
Dengan keluarga & 75 & 65,8 \\
Tinggal sendiri & & \\
Tempat Menjalani Perawatan & 67 & 58,8 \\
Rumah & 47 & 41,2 \\
Rumah Sakit & & \\
Lamanya Menderita Sakit & 67 & 58,7 \\
$<3$ minggu & 37 & 32,5 \\
$3-6$ minggu & 10 & 8,8 \\
$>6$ minggu & & \\
Kemungkinan Tertular & 10 & 8,8 \\
Teman kost & 26 & 22,8 \\
Teman kampus & 3 & 2,6 \\
Keluarga & 66 & 57,9 \\
Lingkungan tempat tinggal & 9 & 7,9 \\
Lain-lain & &
\end{tabular}


Retno : Hubungan Host dan Lingkungan dengan Manifestasi Klinis Hepatitis A

Tabel 3 Distribusi Frekuensi Manifestasi Klinis Hepatitis A (n=114)

\begin{tabular}{lcc}
\hline \multicolumn{1}{c}{ Manifestasiklinis Hepatitis A } & Frekuensi (orang) & Persentase (\%) \\
\hline Ringan & 56 & $49,1 \%$ \\
Sedang & 36 & $31,6 \%$ \\
Berat & 22 & $19,3 \%$ \\
\hline
\end{tabular}

\section{Hasil Penelitian}

Hasil penelitian ini adalah mengenai karakteristik responden, manifestasi klinis penyakit hepatitis A, faktor host dan faktor lingkungan, hubungan faktor host dengan manifestasi klinis penyakit hepatitis A dan hubungan faktor lingkungan dengan manifestasi klinis penyakit hepatitis A. Sebelum pemaparan mengenai manifestasi klinis, faktor host dan faktor lingkungan, hubungan faktor host dengan manifestasi klinis penyakit hepatitis A dan hubungan faktor lingkungan dengan manifestasi klinis penyakit hepatitis A akan ditampilkan karakteristik responden yang dapat dilihat pada tabel 2 .

Hasil penelitian mengenai manifestasi klinis penyakit hepatitis A diketahui bahwa dari 114 responden yang menjadi subjek sampel dalam penelitian ini adalah 56 mahasiswa $(49,1 \%)$ merasakan manifestasi klinis penyakit hepatitis A yang ringan, 36 mahasiswa $(31,6 \%)$ merasakan manifestasi klinis penyakit hepatitis A pada kondisi yang sedang, sedangkan sisanya yaitu 22 mahasiswa $(19,3 \%)$ merasakan manifestasi klinis penyakit hepatitis A pada kondisi yang berat. Data interpretasi di atas dapat dikatakan sebagian besar mahasiswa Universitas X di Bandung menderita penyakit hepatitis A dengan manifestasi klinis ringan.

Hasil penelitian mengenai faktor host dan faktor lingkungan pada mahasiswa Universitas $\mathrm{X}$ diukur dengan cara pengisian kuesioner. Hasil interpretasi dari kuesioner yang telah diisi oleh mahasiswa diketahui bahwa dari 114 responden yang menjadi subjek sampel dalam penelitian ini adalah 46 mahasiswa (40,4\%) faktor host baik dan 68 mahasiswa (59,6\%) faktor host kurang baik. Jadi, berdasarkan data analisis diatas dapat dikatakan bahwa faktor host pada mahasiswa Universitas X kurang baik. Sedangkan faktor lingkungan mahasiswa Universitas $\mathrm{X}$ analisis diatas diketahui bahwa dari 114 responden yang menjadi subjek sampel dalam penelitian ini, 74 mahasiswa $(64,9 \%)$ faktor lingkungan baik, dan 40 mahasiswa $(35,1 \%)$ faktor lingkungan kurang baik. Jadi, berdasarkan data diatas dapat dikatakan bahwa faktor lingkungan pada mahasiswa Universitas X adalah baik.

Hubungan faktor host dengan manifestasi klinis penyakit hepatitis A dapat dilihat pada tabel 5 dan didapatkan bahwa faktor host baik dengan manifestasi klinis penyakit hepatitis A yang ringan sebanyak 22 mahasiswa $(47,8 \%)$ dan faktor host kurang serta dengan manifestasi klinis penyakit hepatitis A ringan sebanyak 34 mahasiswa $(50,0 \%)$. Selain itu, faktor host baik dengan manifestasi klinis penyakit yang sedang sebanyak 12 mahasiswa $(26,1 \%)$ dan faktor host kurang serta manifestasi klinis penyakit hepatitis A sedang sebanyak 24 mahasiswa $(35,3 \%)$. Sedangkan faktor host yang baik dengan manifestasi klinis penyakit yang berat sebanyak 12 mahasiswa $(26,1 \%)$ dan faktor host kurang serta manifestasi klinis penyakit

Tabel 4 Distribusi Frekuensi berdasarkan Faktor Host dan Faktor Lingkungan (n=114)

\begin{tabular}{lcc}
\hline \multicolumn{1}{c}{ Variabel } & Frekuensi (orang) & Persentase (\%) \\
\hline Faktor Host & & \\
Baik & 46 & 40,4 \\
Kurang baik & 68 & 59,6 \\
Faktor Lingkungan & & \\
Baik & 74 & 64,9 \\
Kurang baik & 40 & 35,1 \\
\hline
\end{tabular}


Retno : Hubungan Host dan Lingkungan dengan Manifestasi Klinis Hepatitis A

Tabel 5 Analisis Hubungan antara Faktor Host Mahasiswa dengan Manifestasi Klinis Penyakit Hepatitis A

\begin{tabular}{|c|c|c|c|c|c|c|c|c|c|c|}
\hline \multirow{3}{*}{$\begin{array}{c}\text { Faktor } \\
\text { Host }\end{array}$} & \multicolumn{6}{|c|}{$\begin{array}{c}\text { Manifestasi klinis Penyakit } \\
\text { Hepatitis A }\end{array}$} & \multicolumn{2}{|c|}{ Total } & \multirow[b]{2}{*}{ C.I } & \multirow[b]{2}{*}{$P$ Value } \\
\hline & \multicolumn{2}{|c|}{ Ringan } & \multicolumn{2}{|c|}{ Sedang } & \multicolumn{2}{|c|}{ Berat } & & & & \\
\hline & $f$ & $\%$ & $f$ & $\%$ & $f$ & $\%$ & $f$ & $\%$ & & \\
\hline Kurang & 34 & 50,0 & 24 & 35,3 & 10 & 14,7 & 68 & 100 & $\begin{array}{c}0.046- \\
0.041\end{array}$ & 0.039 \\
\hline Baik & 22 & 47,8 & 12 & 26,1 & 12 & 26,1 & 46 & 100 & & \\
\hline
\end{tabular}

hepatitis A berat sebanyak 10 mahasiswa $(14,7 \%)$. Tingkat kepercayaan sebesar $0.046-$ 0.041 . Hasil uji statistik didapat nilai $p$ value $=0.039<0.05$. Maka dari hasil diatas dapat disimpulkan bahwa terdapat hubungan antara faktor host dengan manifestasi klinis penyakit hepatitis A pada mahasiswa Universitas X di Bandung.

Hasil terakhir pada penelitian ini mengenai hubungan faktor lingkungan dengan manifestasi klinis penyakit hepatitis A pada mahasiswa Universitas $X$ dapat dilihat pada tabel 5, yaitu bahwa faktor lingkungan baik dengan manifestasi klinis penyakit hepatitis A yang ringan sebanyak 37 mahasiswa $(50,0 \%)$, faktor host kurang serta manifestasi klinis penyakit hepatitis A ringan sebanyak 19 mahasiswa (47,5\%). Faktor host baik dengan manifestasi klinis penyakit yang sedang sebanyak 22 mahasiswa $(29,7 \%)$ dan faktor host kurang serta sedang dalam manifestasi klinis penyakit hepatitis A sebanyak 14 mahasiswa $(35,0 \%)$. Sedangkan faktor host yang baik dengan manifestasi klinis penyakit yang berat sebanyak 15 mahasiswa $(20,3 \%)$ dan kurang dalam faktor host serta berat dalam manifestasi klinis penyakit sebanyak tujuh mahasiswa $(17,5 \%)$. Tingkat kepercayaan sebesar 0.002-0.001. Hasil dari uji statistik didapatkan nilai $p$ value $=0.001<0.05$, maka hasil diatas dapat disimpulkan bahwa ada hubungan antara faktor lingkungan dengan manifestasi klinis penyakit hepatitis A pada mahasiswa Universitas X di Bandung. Dan mahasiswa juga masih banyak yang tidak mendapatkan imunisasi HAV.

\section{Pembahasan}

Hasil uji statistik mengenai hubungan faktor host dengan menifestasi klinis penyakit hepatitis A pada mahasiswa Universitas X di Bandung didapatkan $p$ value $<0.05$ yaitu 0.039. Maka dengan demikian hipotesis nol (Ho) ditolak dan yang berlaku adalah hipotesis alternatif (Ha). Dapat disimpulkan bahwa faktor host berhubungan dengan manifestasi klinis penyakit hepatitis A pada mahasiswa Universitas X di Bandung. Manifestasi klinis yang berbeda-beda dari penyakit hepatitis A yang dirasakan oleh mahasiswa tersebut dipengaruhi oleh faktor host masing-masing mahasiswa.

Tabel 6 Analisis Hubungan antara Faktor Lingkungan Mahasiswa dengan Manifestasi Klinis Penyakit Hepatitis A

\begin{tabular}{|c|c|c|c|c|c|c|c|c|c|c|}
\hline \multirow{3}{*}{$\begin{array}{c}\text { Faktor } \\
\text { Ling- } \\
\text { kungan }\end{array}$} & \multicolumn{6}{|c|}{$\begin{array}{c}\text { Manifestasi klinis Penyakit } \\
\text { Hepatitis A }\end{array}$} & \multicolumn{4}{|c|}{ Total } \\
\hline & \multicolumn{2}{|c|}{ Ringan } & \multicolumn{2}{|c|}{ Sedang } & \multicolumn{2}{|c|}{ Berat } & \multirow[b]{2}{*}{ f } & \multirow[b]{2}{*}{$\%$} & \multirow[t]{2}{*}{ C.I } & \multirow[t]{2}{*}{$P$ Value } \\
\hline & f & $\%$ & f & $\%$ & f & $\%$ & & & & \\
\hline Kurang & 19 & 47,5 & 14 & 35,0 & 7 & 17,5 & 40 & 100 & $\begin{array}{c}0,002- \\
0.001\end{array}$ & 0.001 \\
\hline Baik & 37 & 50,0 & 22 & 29,7 & 15 & 20,3 & 74 & 100 & & \\
\hline
\end{tabular}


Retno : Hubungan Host dan Lingkungan dengan Manifestasi Klinis Hepatitis A

Faktor host dari mahasiswa yang kurang baik maka akan memberi peluang terhadap masuknya virus terutama virus hepatitis $\mathrm{A}$. Secara epidemiologi, hepatitis A mempunyai masa inkubasi dalam waktu pendek, menular, dan transmisi secara fekal oral (Long,1996). Panjang fase inkubasi dan manifestasi klinis yang dirasakan saat sakit tergantung kepada dosis inokulum yang ditularkan dan jalur penularan. Semakin besar dosis inokulum maka semakin pendek fase inkubasi hepatitis A (Winarno, 2008). Persistensi virus hepatitis menimbulkan kelainan yang berbeda pada individu yang berbeda juga, tergantung dari konsentrasi partikel virus dan respon imun tubuh seseorang. Semakin besar respons imun tubuh seseorang terhadap virus, maka semakin besar pula kerusakan jaringan hati. Sebaliknya bila tubuh toleran terhadap virus hepatitis A maka kerusakan hati tidak akan terjadi (Sudoyo, 2009). Semakin banyak kerusakan sel-sel hati yang dialami, maka semakin jelas penampilan sakit seseorang (Cahyono, 2009).

Hasil penelitian mengenai hubungan faktor lingkungan dengan manifestasi klinis penyakit hepatitis A pada mahasiswa Universitas $X$ di Bandung, diperoleh data bahwa faktor lingkungan mahasiswa Universitas X di Bandung sudah lebih baik dibandingkan dengan faktor host tetapi masih ada beberapa mahasiswa yang memiliki lingkungan sanitasi yang buruk, sarana MCK yang kurang memadai, dan pengolahan serta penyimpanan makanan yang kurang memperhatikan standar kesehatan.

Hasil uji statistik didapatkan $p$ value $<0.05$ yaitu 0.001 . Maka dengan demikian hipotesis nol (Ho) ditolak dan yang berlaku adalah hipotesis alternatif (Ha). Dari hasil uji statistik dapat disimpulkan bahwa faktor lingkungan berhubungan dengan manifestasi klinis penyakit hepatitis A pada mahasiswa Universitas X di Bandung. Manifestasi klinis hepatitis A yang dirasakan oleh para mahasiswa berbeda-beda. Perbedaan manifestasi klinis dipengaruhi oleh faktor lingkungan tempat tinggal mahasiswa. Sehingga, dapat dikatakan bahwa lingkungan memengaruhi derajat kesehatan manusia (Effendi dkk, 2009). Hipocrates (460-377 SM) berpendapat bahwa penyakit mempunyai hubungan dengan fenomena alam dan lingkungan sekitar (Phyono, 2011).

Prevalensi virus hepatitis A (HAV) berkorelasi dengan standar sanitasi dan tempat tinggal atau rumah dengan ukuran besar (Ramaiah, 2008). Endemisitas HAV yang tinggi, infeksi terjadi karena kondisi higiene dan sanitasi lingkungan yang buruk (Cahyono, 2009). Kembali merujuk pada Ramaiah (2008) bahwa panjang fase inkubasi dan manifestasi klinis yang dirasakan saat sakit tergantung pada dosis inokulum yang ditularkan dan jalur penularan, makin besar dosis inokulum, makin pendek fase inkubasi ini.

Lingkungan adalah agregat dari seluruh kondisi dan pengaruh-pengaruh luar yang memengaruhi kehidupan dan perkembangan suatu individu. Penyebab seseorang menderita sakit karena lingkungan berubah.

\section{Simpulan}

Hasil penelitian ini dapat disimpulkan bahwa mahasiswa Universitas X di Bandung yang menderita penyakit hepatitis A mempunyai manifestasi klinis yang berbeda-beda. Manifestasi klinis yang paling banyak adalah manifestasi klinis ringan yang meliputi terasa tidak enak badan, mudah lelah, lemas, meriang, kehilangan nafsu makan. Pada penelitian ini didapatkan faktor host pada mahasiswa Universitas X kurang baik. Hal ini dikarenakan kurangnya kesadaran dari mahasiswa mengenai kondisi dirinya sendiri yang meliputi personal hygiene, imunisasi, keletihan, dan status gizi yang tidak seimbang.

Hasil penelitian memberikan implikasi agar dapat mengadakan program penyuluhan mengenai masalah kesehatan dan cara pencegahan sedini mungkin pada penyakit terutama hepatitis A.

Pencegahan dini pada penyakit hepatitis A adalah memperhatikan personal hygiene dan lingkungan sekitar. Tindakan pencegahan pada personal hygiene adalah cuci tangan sebelum dan sesudah makan. Selain itu, bagi mahasiswa yang kontak dengan penderita hepatitis A harus mendapat vaksinasi hepatitis $\mathrm{A}$, menghindari pekerjaan yang melelahkan, memahami mengenai istirahat yang cukup, 
Retno : Hubungan Host dan Lingkungan dengan Manifestasi Klinis Hepatitis A

dan memahami diet tinggi protein dan kalori. Diet tinggi protein dan kalori berguna untuk meningkatkan daya tahan tubuh saat banyak kegiatan.

\section{Daftar Pustaka}

Cahyono, S. P. (2009). Hepatitis A cegah penularannya. Yogyakarta: Kanisius.

Efendi, F., \& Makhfudli.(2009). Keperawatan kesehatan komunitas: Teori dan praktik dalam keperawatan. Jilid I. Jakarta: Salemba Medika.

Long, B. C. (1996). Perawatan medikal bedah (suatu pendekatan proses keperawatan). Cetakan I. Bandung: Yayasan Ikatan Alumni Pendidikan Keperawatan.

Najmudin, D. (2011). Beberapa manifestasi klinis hepatitis A untuk dipelajari. Diakses dari: http://www.djamilah-najmuddin.com/ manifestasi klinis-hepatitis-a.

Notoatmodjo, S. (2010). Metodologi penelitian. Jakarta: Rineka Cipta.

Phyono. (2011). Technologi Indonesia dalam
Indonesia peringkat ke-3 jumlah penderita hepatitis. Diakses dari: http://technologyIndonesia.com/kesehatan/phyono,Penyakitmenular/162-indonesia-peringkat-ke-3jumlah-penderita-hepatitis.

Potter, P. A. \& Perry, A. G. (2005). Buku ajar fundamental keperawatan: Konsep proses, dan praktik volume 1 (Edisi ke-4). Alih Bahasa: Renata Komalasari, dkk. Jakarta: EGC.

Ramaiah, S. (2008). All you wanted to know about hepatitis. Jakarta: Bhuana Ilmu Populer.

Riyanto, A. (2011). Aplikasi metodologi penelitian kesehatan. Yogyakarta: Nuha Medika.

Sudoyo, W.A, dkk. (2009). Buku ajar ilmu penyakit dalam (Edisi ke-5). Jakarta: Internal Publishing.

Winarno, B. (2008). Hubungan antara faktor lingkungan dan perilaku dengan kejadian hepatitis A pada taruna akademi kepolikliniksian 2008. Diakses dari: http:// www.scribd.com/doc/67148701/Hepatitis. 